\title{
Grazing Exclusion to Recover Degraded Alpine Pastures Needs Scientific Assessments across the Northern Tibetan Plateau
}

\author{
Chengqun $\mathrm{Yu}^{1}$, Xianzhou Zhang ${ }^{1}$, Jing Zhang ${ }^{2}$, Shaowei Li ${ }^{1}$, Chunqiao Song ${ }^{3}$, Yuzhi Fang ${ }^{1}$, \\ Susanne Wurst ${ }^{4}$ and Jianshuang $\mathrm{Wu}^{1,4, *}$ \\ 1 Lhasa Plateau Ecosystem Research Station, Key Laboratory of Ecosystem Network Observation and Modelling, \\ Institute of Geographic Sciences and Natural Resources Research, Chinese Academy of Sciences, \\ Beijing 100101, China; yucq@igsnrr.ac.cn (C.Y.); zhangxz@igsnrr.ac.cn (X.Z.); leesw@igsnrr.ac.cn (S.L.); \\ fanyuzhi@igsnrr.ac.cn (Y.F.) \\ 2 College of Global Change and Earth System Sciences, Beijing Normal University, Beijing 100875, China; \\ jingzhang@bnu.edu.cn \\ 3 Department of Geography, University of California, Los Angeles, CA 90095, USA; chunqiao@ucla.edu \\ 4 Functional Biodiversity, Dahlem Center of Plant Science, Free University of Berlin, 14195 Berlin, Germany; \\ s.wurst@fu-berlin.de \\ * Correspondence: wujs.07s@igsnrr.ac.cn; Tel.: +86-10-6488-8176
}

Academic Editor: Vincenzo Torretta

Received: 11 October 2016; Accepted: 7 November 2016; Published: 10 November 2016

\begin{abstract}
The northern Tibetan Plateau is the most traditional and important semi-nomadic region in Tibet. The alpine vegetation is sensitive and vulnerable to climate change and human activities, and is also important as an ecological security in protecting the headwaters of major rivers in Asia. Therefore, the Tibetan alpine grasslands have fundamental significance to both Mainland China and South Asia. The pasture degradation, however, likely threatens the livelihood of residents and the habitats of wildlife on this plateau. Since 2004, the government has launched a series of ecological restoration projects and economic compensatory payment polices. Many fences were additionally built on degraded pastures to prevent new degradation, to promote functionality recovery, and to balance the stocking rate with forage productivity. The grazed vs. fenced paired pastures across different zonal grassland communities along evident environmental gradients provide us with a natural comparative experiment platform to test the relative contributions of natural and anthropogenic factors. This study critically reviews the background, significance of and debates on short-term grazing exclusion with fences in this region. We also aim to figure out scientific and standardized workflows for assessing the effectiveness of grazing exclusion and compensatory payments in the future.
\end{abstract}

Keywords: alpine grasslands; climate change; compensatory payment; fencing; grazing enclosure; livestock management

\section{Climate Changes and Husbandry Development in Tibet}

The alpine grasslands on the Tibetan Plateau have increasingly gained attention for their sensitivity and vulnerability to climate change and human activities over the past decades [1]. The air temperature over this plateau has risen by $0.3{ }^{\circ} \mathrm{C}$ per decade since the $1960 \mathrm{~s}$, nearly three times the global warming rate [2]. In the northern Tibetan plateau, it has warmed by $0.5{ }^{\circ} \mathrm{C}$ per decade from 1979 to 2008 (Figure 1), which is even faster than other areas of this plateau and inland areas of China. Precipitation followed no obvious trend, but exhibited evident inter-annual and decadal variability during the same period (Figure 1). Because of the continuous warming and no evident increment in precipitation, the northern Tibetan Plateau went through a warmer and drier trajectory over the past decades. 
Meanwhile, human activities are getting increasingly intensified in this region. The population increased to 154,000 (approximately 0.2 persons per $\mathrm{km}^{2}$ land) in 2012, and meat output has nearly tripled from 23.6 to 66.2 million $\mathrm{kg}$ (Figure 1). The total number of domestic animals started to decrease from 2005 partly due to the grazing exclusion program laughed in 2004 (Figure 1). However, overgrazing is still the most serious problem faced by the local societies. Climate warming and overgrazing together have contributed to 15.3 million hectares of grassland degradation, accounting for $24.9 \%$ of available alpine pastures on the northern Tibetan Plateau [3].

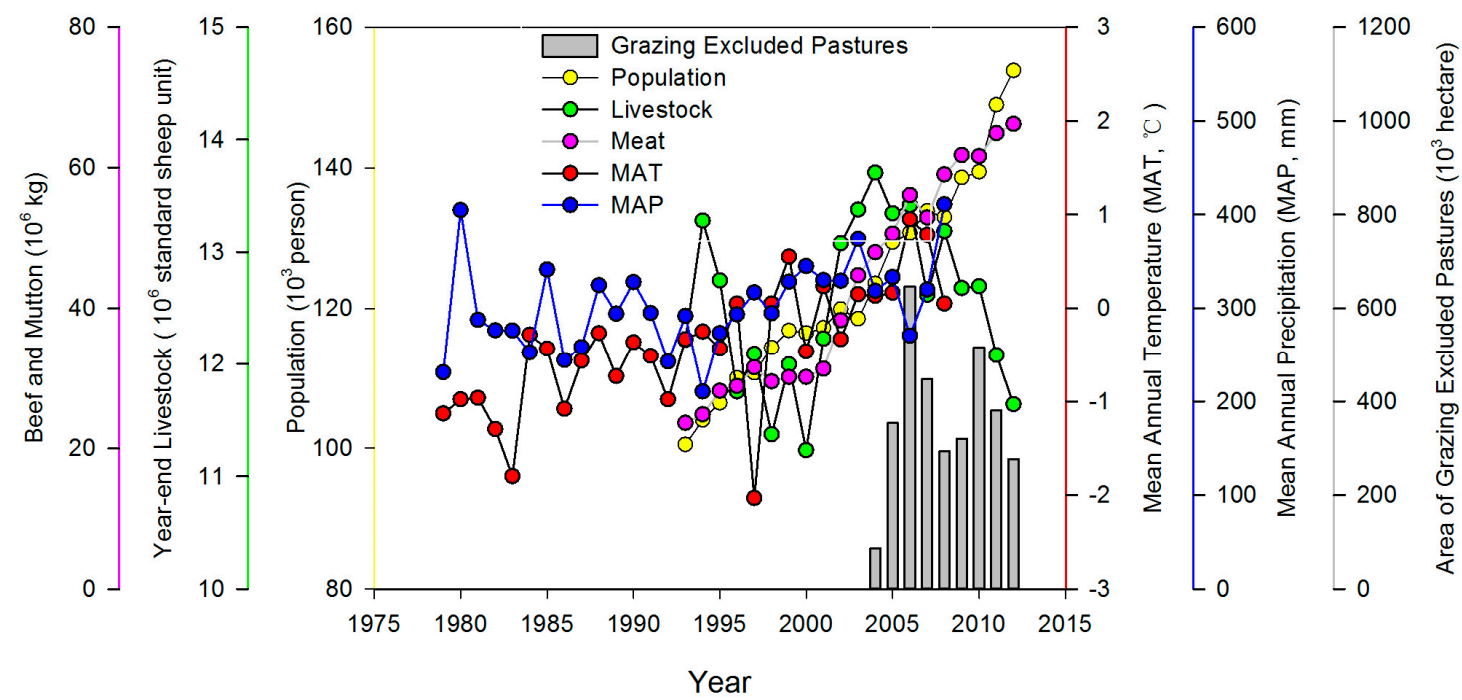

Figure 1. Time series of social-economic indices including population (thousand persons), livestock (million standard sheep units) and meat output (million kg) from 1993 to 2012; climatic variables including mean annual air temperature (MAT, ${ }^{\circ} \mathrm{C}$ ) and annual precipitation (MAP, mm) from 1979 to 2008; and the area of grazing excluding pastures with fences built from 2004 to 2012 on the northern Tibetan Plateau. To assess grassland capacity, yaks have been transformed into standard sheep units as one yak = five sheep.

\section{Fence Construction and Compensatory Payment Policies}

To conserve alpine grasslands, the government started to construct metal fences on severely degraded pastures that had been invaded by poisonous weeds or had been considerably decreased in vegetation coverage or forage production. In 2012, the total area of fences had increased up to 3.32 million hectares (Figure 2). A new compensatory payment policy was launched in 2011 . According to this policy, local herdsman families are allowed to be allowanced by approximately $90 \mathrm{RMB}(100 \mathrm{RMB}=13.4 \mathrm{EUR},=12.1 \mathrm{GBP}$, and $=14.8 \mathrm{USD})$ per hectare every year if their degraded pastures have been fenced from domestic animals, and the herdsman families can also be awarded by 22.5 RMB per hectare every year if their healthy pastures are managed at a reasonable stocking rate, which has been specified for each different grassland type and approximately referred to their average forage productivity [3].

However, the extent and the magnitude of the ecological benefits potentially resulting from fencing and compensatory payments are not seriously considered and assessed. Therefore, it is still a big challenge to disentangle the relative contributions of climate change, grazing exclusion and economic policies to the functional recovery of degraded pastures. In detail, there is still lack of knowledge and debate on where and how long to fence, and how the fencing works, between policy-makers and residents. 


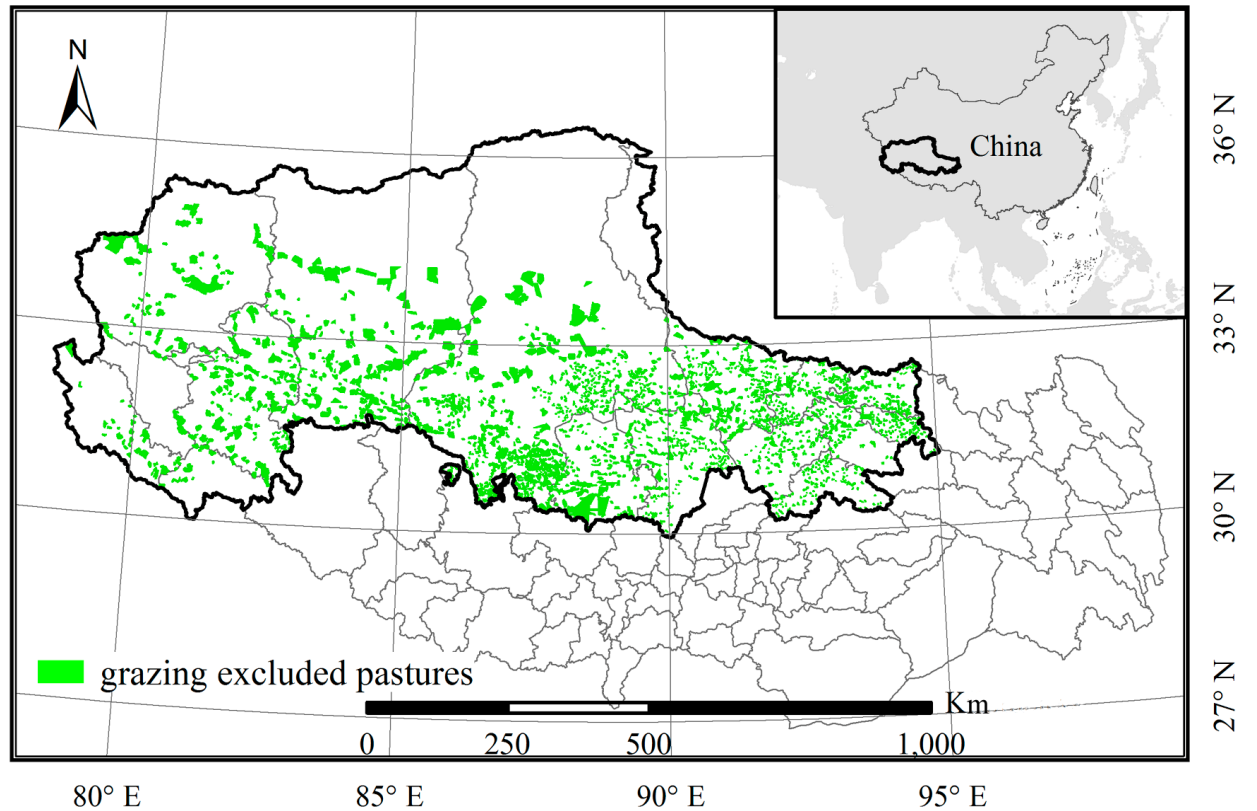

Figure 2. The spatial distribution of grazing-excluded pastures with fences that were constructed on the northern Tibetan Plateau during 2004-2012. The bold lines indicate the study area, the northern Tibetan Plateau which includes both Agari Prefecture and Nagchu Prefecture. The limits are for the county boundaries in the Tibet Autonomous Region, China.

\section{Current Assessments on Short-Term Grazing Exclusion}

Using comparative designs with grazed vs. fenced paired plots surveyed, a few studies have tested and compared the differences in biodiversity and productivity (above-ground biomass) as well as soil properties within and across zonal alpine grassland types on the northern Tibetan Plateau. For example, the short-term (three to four years) fencing did not change plant species richness or the manner of species diversity indices responding to the regional climate gradients in this region $[4,5]$. However, the short-term fencing has changed the relative dominance of different functional groups that have differential strategies of biomass allocation between above- and below-ground organs in response to the regional changes in water availability across the northern Tibetan plateau [6,7]. The biomass of dominant grasses and sedges in short-term fenced pastures were increased on average by $10.47 \mathrm{~g} \cdot \mathrm{m}^{-2} \cdot$ year $^{-1}$ for alpine meadow, $10.17 \mathrm{~g} \cdot \mathrm{m}^{-2} \cdot \mathrm{year}^{-1}$ for alpine steppe, and $5.32 \mathrm{~g} \cdot \mathrm{m}^{-2} \cdot$ year $^{-1}$ for desert steppe, by a five-year grazing exclusion, and compared to adjacent pastures under grazing [8]. Therefore, a long-term grazing exclusion would likely result in productivity changes of different functional groups due to their specific responses to the spatial and temporal climatic changes [9].

However, whether the short-term grazing exclusion can improve the soil properties or nutrient content of degraded alpine pastures is still under debate. In general, no significant impacts of short-term grazing exclusion were found on either soil properties or nutrients in degraded alpine grasslands across the northern Tibetan Plateau [10]. However, soil organic carbon was reported remarkably reduced at alpine desert steppes [11] and was enhanced at alpine meadows [12] due to the short-term grazing exclusion. Current studies consistently indicate that climate changes, especially in precipitation during the plant-growing months, likely limit the spatio-temporal effectiveness of fences and that the community assembly of plant functional groups mainly controls the manner of forage productivity in response to grazing exclusion [9,13]. However, these studies cannot offer more mechanistic knowledge and clearer indications on how to make the spatial layout of grazing exclusions more reasonable and how to answer the question on the most suitable duration of the grazing exclusions. 


\section{Scientific Assessment Workflows Are Recommended}

To scientifically assess the influences of fences on the ecological recovery of degraded alpine pastures, we recommend the following workflows (Figure 3). Firstly, the extent, magnitude and causes of degradation (recovery) should be clarified in as much detail as possible [14]. This is not only related to the question of where to fence but also to the question of whether the fencing is effective and economical. The changing climate conditions likely exceed fencing in influencing the recovery process where the degradation was primarily caused by warming or drought [15]. Secondly, the biodiversity studies focus should move from species richness to plant functional trait diversity [16,17], to reach more comprehensive and mechanistic understanding of how alpine grasslands respond to climate changes and anthropogenic activities (including grazing, fencing and economic policies). Increasing evidence indicates that plant functional trait diversity can distinguish and predict how grassland communities respond to grazing along climatic gradients [18-22]. Because ecological processes are likely non-linear in response to external drivers and various factors may interact directly or indirectly to affect ecosystem functions [23,24], the causal ecological network model is recommended [25,26]. Thirdly, a long-term reliable observation plan with grazed vs. fenced paired plots across multiple spatial scales is necessary to answer how long to fence. As Körner [27] suggests, the long-term observations across different spatial scales can be merged for predicting potential changes in alpine ecosystem functions in the context of ongoing climatic warming. Finally, multiple ecosystem services, not only supporting livestock capacity but also relating to wild animals, should be considered when assessing the ecological influences of fences on the Tibetan Plateau [28,29].

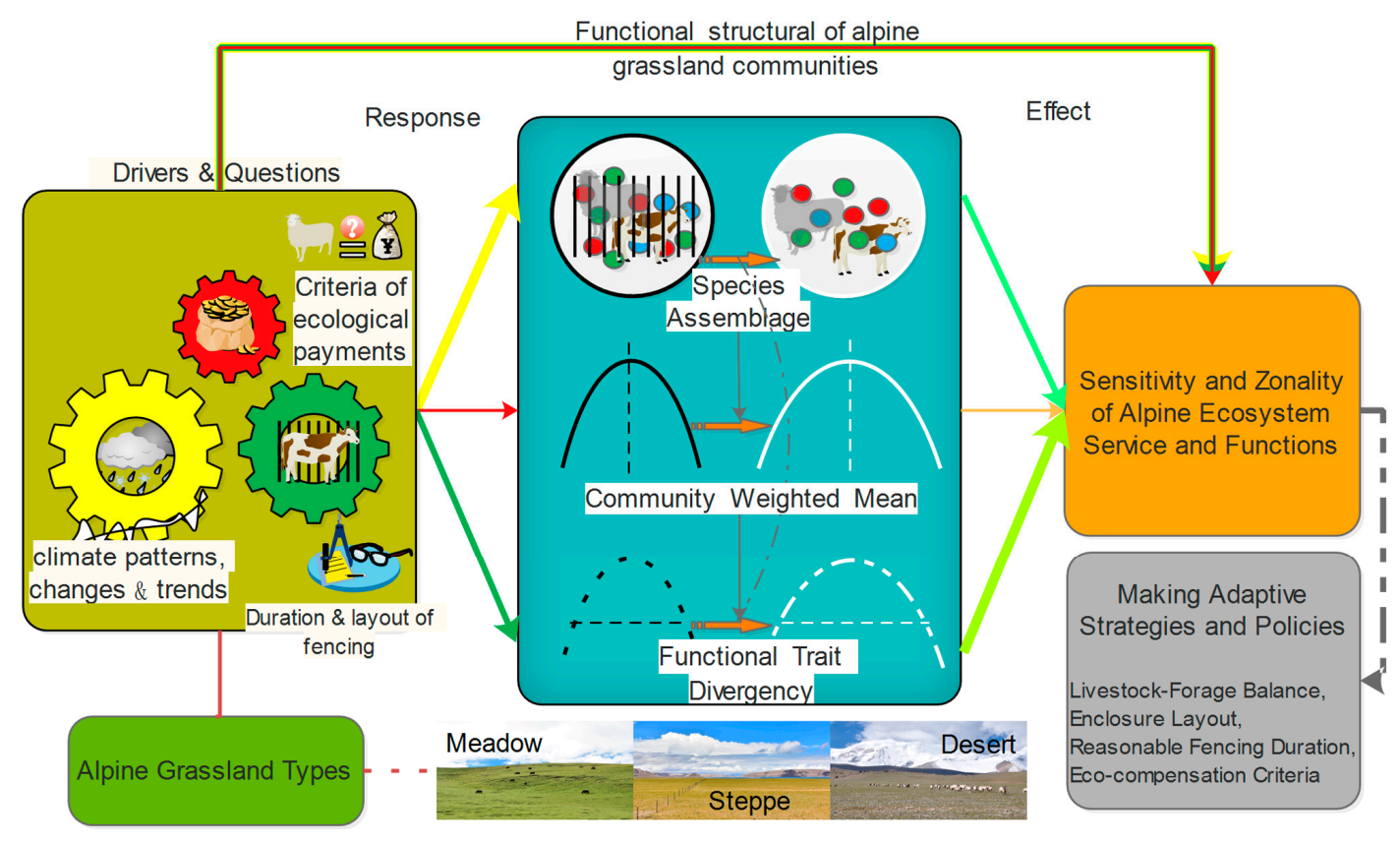

Figure 3. A long-term research framework based community structure and ecosystem functionality of alpine grasslands on the northern Tibetan Plateau under the ongoing climate change and the current ecological and economic policies.

Acknowledgments: This research is supported by the Chinese Academy of Sciences (XDB03030401), the Ministry of Science and Technology of China (SQ2016YFSF030008, 2014BAD14B006), and the National Natural Sciences Foundation of China (41401070, 41571042). Jianshuang Wu has been awarded an international postdoc fellowship by the Alexander von Humboldt Foundation, Germany.

Author Contributions: Chengqun $\mathrm{Yu}$ and Jianshuang $\mathrm{Wu}$ conceived and designed the research together, and Jianshuang $\mathrm{Wu}$ wrote the manuscript; Shaowei Li and Yuzhi Fang collected and analyzed the data, and Chunqiao Song revised Figure 2; Jing Zhang, Xianzhou Zhang and Susanne Wurst contributed to the interpretations of the results. All the authors have contributed to this work. 
Conflicts of Interest: The authors declare no conflict of interest. The founding sponsors had no role in the design of the study; in the collection, analyses, or interpretation of data; in the writing of the manuscript, and in the decision to publish the results.

\section{References}

1. Yao, T.; Thompson, L.G.; Mosbrugger, V.; Zhang, F.; Ma, Y.; Luo, T.; Xu, B.; Yang, X.; Joswiak, D.R.; Wang, W.; et al. Third Pole Environment (TPE). Environ. Dev. 2012, 3, 52-64. [CrossRef]

2. Qiu, J. The Third Pole. Nature 2008, 454, 393-396. [CrossRef] [PubMed]

3. Tibet Autonomous Region Bureau of Statistics, Tibet General Team of Investigation under the NBS. Tibet Statistical Yearbook 2015; China Statistics Press: Beijing, China, 2015.

4. Wu, J.S.; Zhang, X.Z.; Shen, Z.X.; Shi, P.L.; Yu, C.Q.; Song, M.H.; Li, X.J. Species richness and diversity of alpine grasslands on the Northern Tibetan Plateau: Effects of grazing exclusion and growing season precipitation. J. Resour. Ecol. 2012, 3, 236-242.

5. Yan, Y.; Lu, X.Y. Is grazing exclusion effective in restoring vegetation in degraded alpine grasslands in Tibet, China? PeerJ 2015, 3, e1020. [CrossRef] [PubMed]

6. Wu, J.S.; Shen, Z.X.; Zhang, X.Z.; Shi, P.L. Biomass allocation patterns of alpine grassland species and functional groups along a precipitation gradient on the Northern Tibetan Plateau. J. Mt. Sci. 2013, 10, 1097-1108. [CrossRef]

7. Wu, J.S.; Shen, Z.X.; Shi, P.L.; Zhou, Y.T.; Zhang, X.Z. Effects of grazing exclusion on plant functional group diversity alpine grasslands along a precipitation gradient on the Northern Tibetan Plateau. Arct. Antarct. Alp. Res. 2014, 46, 419-429. [CrossRef]

8. Wu, J.S.; Zhang, X.Z.; Shen, Z.X.; Shi, P.L.; Yu, C.Q.; Chen, B.X. Effects of livestock exclusion and climate change on aboveground biomass accumulation in alpine pastures across the Northern Tibetan Plateau. Chin. Sci. Bull. 2014, 59, 4332-4340. [CrossRef]

9. Wu, J.S.; Shen, Z.X.; Zhang, X.Z. Precipitation and species composition primarily determine the diversity-productivity relationship of alpine grasslands on the Northern Tibetan Plateau. Alp. Bot. 2014, 1, 13-25. [CrossRef]

10. Lu, X.; Yan, Y.; Sun, J.; Zhang, X.; Chen, Y.; Wang, X.; Cheng, G. Short-term grazing exclusion has no impact on soil properties and nutrients of degraded alpine grassland in Tibet, China. Solid Earth 2015, 6, 1195-1205. [CrossRef]

11. Wu, J.S.; Zhang, X.Z.; Shen, Z.X.; Shi, P.L.; Xu, X.L.; Li, X.J. Grazing-exclusion effects on aboveground biomass and water-use efficiency of alpine grasslands on the Northern Tibetan Plateau. Rangel. Ecol. Manag. 2013, 66, 454-461. [CrossRef]

12. Xiong, D.P.; Shi, P.L.; Sun, Y.L.; Wu, J.S.; Zhang, X.Z. Effects of grazing exclusion on plant productivity and soil carbon, nitrogen storage in alpine meadows in northern Tibet, China. Chin. Geogr. Sci. 2014, 24, 488-498. [CrossRef]

13. Sun, J.; Wang, X.; Cheng, G.; Wu, J.; Hong, J.; Niu, S. Effects of grazing regimes on plant traits and soil nutrients in an alpine steppe, Northern Tibetan Plateau. PLoS ONE 2014, 9, e108821. [CrossRef] [PubMed]

14. Harris, R.B. Rangeland degradation on the Qinghai-Tibetan plateau: A review of the evidence of its magnitude and causes. J. Arid Environ. 2010, 74, 1-12. [CrossRef]

15. Chen, B.X.; Zhang, X.Z.; Tao, J.; Wu, J.S.; Wang, J.S.; Shi, P.L.; Zhang, Y.J.; Yu, C.Q. The impact of climate change and anthropogenic activities on alpine grassland over the Qinghai-Tibet Plateau. Agric. For. Meteorol. 2014, 189, 11-18. [CrossRef]

16. McGill, B.J.; Enquist, B.J.; Weiher, E.; Westoby, M. Rebuilding community ecology from functional traits. Trends Ecol. Evol. 2006, 21, 178-185. [CrossRef] [PubMed]

17. Violle, C.; Navas, M.L.; Vile, D.; Kazakou, E.; Fortunel, C.; Hummel, I.; Garnier, E. Let the concept of trait be functional! Oikos 2007, 116, 882-892. [CrossRef]

18. Díaz, S.; Noy-Meir, I.; Cabido, M. Can grazing response of herbaceous plants be predicted from simple vegetative traits? J. Appl. Ecol. 2001, 3, 497-508. [CrossRef]

19. De Bello, F.; Lepš, J.A.N.; Sebastià, M.-T. Predictive value of plant traits to grazing along a climatic gradient in the Mediterranean. J. Appl. Ecol. 2005, 42, 824-833. [CrossRef]

20. De Bello, F.; Lepš, J.; Sebastià, M.-T. Variations in species and functional plant diversity along climatic and grazing gradients. Ecography 2006, 29, 801-810. [CrossRef] 
21. Niu, K.C.; Zhang, S.T.; Zhao, B.B.; Du, G.Z. Linking grazing response of species abundance to functional traits in the Tibetan alpine meadow. Plant Soil 2010, 330, 215-223. [CrossRef]

22. Garcia, C.; Schellberg, J.; Ewert, F.; Bruser, K.; Canales-Prati, P.; Linstadter, A.; Oomen, R.J.; Ruppert, J.C.; Perelman, S.B. Response of community-aggregated plant functional traits along grazing gradients: Insights from African semi-arid grasslands. Appl. Veg. Sci. 2014, 17, 470-481. [CrossRef]

23. Saatkamp, A.; Römermann, C.; Dutoit, T. Plant functional traits show non-linear response to grazing. Folia Geobot. 2010, 45, 239-252. [CrossRef]

24. Banegas, N.; Albanesi, A.; Pedraza, R.; Dos Santos, D. Non-linear dynamics of litter decomposition under different grazing management regimes. Plant Soil 2015, 393, 47-56. [CrossRef]

25. Grace, J.B.; Adler, P.B.; Stanley Harpole, W.; Borer, E.T.; Seabloom, E.W.; Stevens, C. Causal networks clarify productivity-richness interrelations, bivariate plots do not. Funct. Ecol. 2014, 28, 787-798. [CrossRef]

26. Valencia, E.; Maestre, F.T.; Le Bagousse-Pinguet, Y.; Quero, J.L.; Tamme, R.; Börger, L.; García-Gómez, M.; Gross, N. Functional diversity enhances the resistance of ecosystem multifunctionality to aridity in Mediterranean drylands. New Phytol. 2015, 206, 660-671. [CrossRef] [PubMed]

27. Körner, C. Alpine Plant Life: Functional Plant Ecology of High Mountain Ecosystems; Springer: Berlin, Germany, 2003.

28. Woodroffe, R.; Hedges, S.; Durant, S.M. To fence or not to fence. Science 2014, 344, 46-48. [CrossRef] [PubMed]

29. Luo, Z.; Jiang, Z.; Tang, S. Impacts of climate change on distributions and diversity of ungulates on the Tibetan Plateau. Ecol. Appl. 2015, 25, 24-38. [CrossRef] [PubMed]

(C) 2016 by the authors; licensee MDPI, Basel, Switzerland. This article is an open access article distributed under the terms and conditions of the Creative Commons Attribution (CC-BY) license (http:/ / creativecommons.org/licenses/by/4.0/). 